\title{
HEAVY METALS ACCUMULATION IN RIPARIAN VEGETATION IN BAIUT METALLOGENIC AREA, MARAMURES COUNTY (ROMANIA)
}

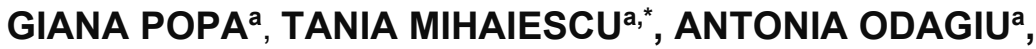 \\ RADU MIHAIESCU ${ }^{\mathrm{b}}$, CLAUDIA BALINT ${ }^{\mathrm{a}}$, ION OLTEAN ${ }^{\mathrm{a}}$
}

\begin{abstract}
The present study was focused on evaluating the manner in which heavy metals, originated from natural and anthropic sources (former mining activity in Baiut metallogenic area), in the upper basin of the Lapus River, transferred into sediments and accumulated in the riparian vegetation. Total concentrations ofPb, $\mathrm{Ni}$, and $\mathrm{Cd}$, classified as priority hazardous substances in the WFD, were measured in samples of water, sediments and some emergent flora species (Equisetum fluviatile, Myosotonaquaticum, Carexaquatilis, Salix fragilis, Mentha aquatica, Juncus spp.), in 4 selected sections of the Lapus River, including a reference section (a pollution free area). The heavy metal concentration in collected samples were determined by atomic adsorption spectrometry. In all the monitored sections the heavy metals concentrations were higher in plants than in sediments or water samples. The highest concentrations were recorded for $\mathrm{Pb}$, then for $\mathrm{Ni}$ and lastly for $\mathrm{Cd}$ in the genus Carex and Salix in the most contaminated river section. The results of the study show that the ability to accumulate heavy metals differs between species, and affinity for a particular metal depends on its bioavailability.
\end{abstract}

Keywords: heavymetals, riparian vegetation, surface water, mining activity, Lapus River

a University of Agricultural Sciences and Veterinary Medicine, Faculty of Agriculture, 3-5 Manastur str., RO-400372, Cluj-Napoca, Romania

b Babess-Bolyai University, Faculty of Environmental Science and Engineering, 30 Fantanele str., RO-400294, Cluj-Napoca, Romania

*Corresponding author: tania.mihaiescu@usamvcluj.ro 


\section{INTRODUCTION}

The presence of heavy metals in the aquatic environment, in a variety of complex chemical forms, continues to cause concern on account of the changes it generates to the biodiversity of aquatic communities and implicitly due the risk that some organisms may develop resistance to the new environmental conditions.

The reaction of aquatic organisms to growing concentrations of heavy metal corresponds to the responsiveness of each species, to the intensity and length of the exposure and to the toxicity level and form of the metal in question [1].

Resistance to heavy metals can be obtained through either of two ways: avoidance, through which a plant is externally protected from stress and tolerance, through which a plant survives internal stress effects [2].

From the physiological point of view the survival of a plant in its specific environment is based on its requirements of chemical elements needed for a normal metabolism (macronutrients, micronutrients and the benefit elements) [3] and/or on the tolerance to theexcess of essential and metaboliccally nonessential elements [4]. Therefore, plantsneed to adopt their physiological process to the environment in which they germinate, and their beneficial metabolic charactersneed to be transferred to next generation by changing the genetic structure of the local population [5].

In most cases metallogenetic environments are contaminated with more than one type of metal, in potentially toxic concentrations, consequently plants develop multiple tolerances. In some cases, plants develop low-level co-tolerance, for metals with low concentration in their environment [6].

The dividing line between tolerance and non-tolerance for aquatic organisms is their ability to root, survive and reproduce in soil substrates contaminated with heavy metals [1].

Consequently, ecosystems tend to adapt to the new conditions, either with species tolerant to heavy metal contamination, or with the appearance of dominant species to the detriment of diversity. The occurrence of such species can constitute an indicator for the contamination level and for bad ecological conditions.

Heavy metal pollution can determine severe phytotoxic actions on plant species, with implications on their genotype, guiding their development selectively towards greater heavy metal tolerance [1].

Aquatic plants are fundamental for the structure and functioning of aquatic habitats [7]. Additionally, high degrees of visibility for aquatic plants indicate a less polluted environment [8].

"Chemical pollution" has a chronic and acute effect on aquatic organisms. The accumulation of polluting substances in ecosystems and the disappearance of biodiversity and habitats are the result of pollution with some heavy metals $(\mathrm{Cd}, \mathrm{Hg}, \mathrm{Ni}$ and $\mathrm{Pb}$ ). These heavy metals are considered 
priority contaminants, with proven significant risks to the water environment. According to Water Framework Directive [9] and to the Environmental Quality StandardsDirective [10], these substances relate to different environmental objectives set for them and to their particular definition in differentiated legislative contexts.

Taking into account that some species have developed such a high degree of tolerance that they can survive and thrive in environments with metallogenic substrates, the determination of the bioavailability of metals and of the bioaccumulation and concentration of heavy metals in plants is very relevant today. The first sign of bioavailability is bioaccumulation, when an organism absorbs a part of the polluting substance [11].

The study focuses on the water body Lapus - "Izvoare - Suciu and the tributaries" RORW2.1.66_B1, analyzing the section between the Izvorul AlbNegru (the reference) section and the Lapusul Romanesc section, which conforms to the RO 01 typology (according to the WFD) and which captures the significant impact of mining activity in Băiuț metallogenic area. Its chemical state risks not reaching the target of the Water Framework Directive [9] and constitutes an exception to the general good status of the river.

In 2006, prior to the cessation of waste depositing and implicity of mining activity (obligation included in the EU Ascension Treaty of Romania), the water quality of the Lapus River showed an evident impact of heavy metal presence. In all sections (Izvorul Alb Negru, Lapusel, Razoare and Bucsag) monitored by the basin water authority, the measured values for $\mathrm{Pb}$ and $\mathrm{Cd}$ determined the fifth grade, the most unfavorable, for the Lapus River (referred to the Order no.161 / 2006[12]). If the measured values for 2006 are related to the EQS limits provided by the current EU legislation[10], they exceed the allowed limits for cadmium in all sections and for lead in the Lapusel and Bucsag sections.

Based on the evaluation data on the water quality status and, more precisely, the chemical status of the Lapus River (owned by the water basin authority), taking into account all the conformations, it is found that this body of water has a chemical state classified as "bad".

The aim of this study is to evaluate the bioaccumulation level (Bioaccumulation factor, BAF) in riparian vegetation, of those heavy metals which are defined by the EQS Directive as priority substances ( $\mathrm{Cd}, \mathrm{Ni}, \mathrm{Pb})$.

\section{RESULTS AND DISCUSSION}

A first assessment of the concentration levels of heavy metals $(\mathrm{Cd}$, $\mathrm{Ni}, \mathrm{Pb}$ ) of sediment and plant samples was undertaken in September 2016, through the sampling of the sedimentary layer surface (4 sections) and helophyte plants sampling (same 4 sections). 


\section{Sediments}

In each section an instanter sediment sample was collected from the minor riverbed of the Lapus River, along with a $\mathrm{pH}$ measurement conducted at the same location.

The results obtained from the determination of heavy metals concentrations are presented in Table 1.

The dates submitted in Table 1 include water results from the surveillance monitoring sets by the water basin authority for $\mathrm{Pb}, \mathrm{Ni}$ and $\mathrm{Cd}$, in two sections on the Lapus River (Izvorul Alb Negru, Lapusul Romanesc) for chemical status evaluation on "Izvoare - Suciu and the tributaries" water body. The values refer to the annual mediate of monthly determinations for $\mathrm{Pb}, \mathrm{Ni}$ and $\mathrm{Cd}$. The difference of concentrations between the two sections, upstream and downstream along the Lapus River, indicates the existence of significant pressures with heavy metals.

Table 1. Levels of heavy metal concentration in the studied sections of the Lapus River

\begin{tabular}{|c|c|c|c|c|c|c|}
\hline Sampling point & $\begin{array}{c}\text { Sample } \\
\text { code }\end{array}$ & $\begin{array}{c}\text { Sample } \\
\text { type }\end{array}$ & $\mathbf{C d}$ & $\mathbf{N i}$ & $\mathbf{P b}$ & $\begin{array}{c}\text { pHon } \\
\text { water }\end{array}$ \\
\hline $\begin{array}{c}\text { Lapus River upstream from } \\
\text { Băiutsettlement (background } \\
\text { reference section) }\end{array}$ & $\mathrm{S} 1$ & $\begin{array}{c}\text { Sediment } \\
{[\mathrm{mg} / \mathrm{kg}]}\end{array}$ & 1.6 & 19.2 & 42.5 & 7.3 \\
\hline $\begin{array}{c}\text { Lapus River downstream from the } \\
\text { mineshaft }\end{array}$ & $\mathrm{S} 2$ & $\begin{array}{c}\text { Sediment } \\
{[\mathrm{mg} / \mathrm{kg}]}\end{array}$ & 7.7 & 60.6 & 670.7 & 3.1 \\
\hline $\begin{array}{c}\text { Lapus River downstream from } \\
\text { Bloaja pond impact area }\end{array}$ & $\mathrm{S} 3$ & $\begin{array}{c}\text { Sediment } \\
{[\mathrm{mg} / \mathrm{kg}]}\end{array}$ & 2.0 & 50.8 & 651.8 & 3.2 \\
\hline $\begin{array}{c}\text { Lapus River downstream 2 km } \\
\text { from Bloaja pond impact area }\end{array}$ & $\mathrm{S} 4$ & $\begin{array}{c}\text { Sediment } \\
{[\mathrm{mg} / \mathrm{kg}]}\end{array}$ & 2.6 & 47.9 & 618.2 & 3.4 \\
\hline Lapus River - Izvorul Alb Negru & $\mathrm{SA}$ & $\begin{array}{c}\text { Water } \\
{[\mathrm{mg} / \mathrm{l}]}\end{array}$ & 0.1 & 0.8 & 0.4 & 7.2 \\
\hline Lapus River - LapusulRomanesc & $\mathrm{SB}$ & $\begin{array}{c}\text { Water } \\
{[\mathrm{mg} / \mathrm{l}]}\end{array}$ & 2.6 & 13.9 & 0.5 & 7.2 \\
\hline
\end{tabular}

The following aspects are noticeable. The sediment load of $\mathrm{Cd}, \mathrm{Ni}$ and $\mathrm{Pb}$ at the recorded concentrations in the reference area indicate the metallogenic area of the natural background, especially $\mathrm{Cd}$ concentrations where the determined value is greater than the $0.8 \mathrm{mg} / \mathrm{kg}$ limit [Order 161/2006]. All $\mathrm{Cd}, \mathrm{Ni}$ and $\mathrm{Pb}$ concentrations are higher than the allowed limits $(0.8 \mathrm{mg} / \mathrm{kg}$, $35 \mathrm{mg} / \mathrm{kg}, 85 \mathrm{mg} / \mathrm{kg}$ ) in the next 3 sections, with the maximum amount being present in the second section (downstream from the mineshaft). The inflow of uncontaminated water from the Strambu Baiut tributary, located right after section 2, diminishes the heavy metal concentration level of the 460 
sediment in section 3 , to 2.46 times the allowed limit. In section S4 the Cd amounts are 3.22 times the allowed limit, due to the cumulative effect of the acid mining waters and the tailing pond.

Based on the basins authority data for the year 2016, the highest level of water contamination in the studied sector of the Lapus River was recorded in September, when concentrations of $\mathrm{Cd}, \mathrm{Ni}$ and $\mathrm{Pb}$ were 33, 16 and 2.3 times greater than the EQS parameters for a pH of 6.17. The analysis and processing of data recorded throughout 2016 determined the classification of the entire "Lapus-Izvoare cf. Suciu and tributaries" body of water as having a poor chemical state based on the criteria in the "Water Framework Directive" (WFD)[9].

Compared with the $\mathrm{Cd}, \mathrm{Ni}$ and $\mathrm{Pb}$ concentrations measured in water, those found in sediments are much higher, especially for $\mathrm{Ni}$ and $\mathrm{Pb}$. Based on $\mathrm{pH}$, one of the factors known as being a determinant for the solubility and availability of plants for metals, and taking into account that the rivers $\mathrm{pH}$ value at the inflow of mine water and tailings (measured during sediment sampling) is around 3.2, the solubility of metals is growing. The absorption process is more important than the precipitation of solids in the decrease of the concentration of metal ions in acidic conditions, while the reverse is true for alkaline conditions [13]. As such, absorption for $\mathrm{Pb}$ becomes significant at $\mathrm{pH} 3-5$, and for $\mathrm{Cd}$ at $\mathrm{pH}$ 5-6.5 [14], this phenomenon is confirmed by the results of the studied sections.

The water basin authority highlighted this specific behavior of metal absorbtion through the monitoring regime established across 2016, for the water evacuated out of the mineshaft (Breiner) in the Lapus River.The average flow of the evacuated waters was approx. $3 \mathrm{l} / \mathrm{s}$ and a pH between 2.9 and 5.6, the pollutants were found at the following levels: sulphates: $680-1160 \mathrm{mg} / \mathrm{l} /$ $600 \mathrm{mg} / \mathrm{l}$ allowed [HG 352/2005]; Cd: 3,73 - 67,34 $\mathrm{\mu g} / \mathrm{l} /$ 0,2 mg/l allowed; Fe: 5,46 - 121,3 mg/l / 5 mg/l allowed; Ni: 6,5 - 269,6 $\mu \mathrm{g} / \mathrm{l} /$ 0,5 mg/l allowed; Zn: 0,973 - 32,95 mg/l / 0,5 mg/l allowed; Hg: 0,006 - 0,042 $\mu \mathrm{g} / \mathrm{l} /$ 0,05 mg/l allowed; Pb: 3,992 - $262 \mu \mathrm{g} / \mathrm{l} /$ 0,2 mg/l allowed.

If for the mine waters the concentrations are known, for the pond, being a diffuse pollution source, we can only observe the visual effect it has on the Lapus River and estimate the ponds contamination level. The eroded and active layer of the ponds surface, disperses acid and high salt-content particles towards the river area, generating substantial qualitative changes on it.

From the same sections were collected plant species anchored in the soil, depending on representativity and abundance so as to be relevant for the study. The species diversity was lower, even in section S1 (only metallogenetic background) at the final vegetative period. The plants were washed by the periphyton (all the bodies that live submerged on aquatic plants organisms) and the sediment, being preserved in plastic bags. 
In Table 2 the identified species from the monitoring sections and the results of phytotoxicologic determinations for $\mathrm{Ni}, \mathrm{Pb}, \mathrm{Cd}$ and $\mathrm{Zn}$ are presented.

The diversity of plants and their abundance is limited and decreases from one section to another, and along the crossing of highly contaminated sections the plants change not only their coloration but also their terrestrial structure, much less developed, while the structure of the roots is more branched and filamentous. With the exception of the Carex species which is present in all sections, the diversity of the rest of the identified plants changes, with the most contaminated section 3 having only Carex and Salix species present.

As for the concentrations of metals measured in plants the highest was found in section S3, followed by section S4 and section S1. Section S2 was poorly represented by the relevant plants.

Table 2. Heavy metal concentrations in identified plant species

\begin{tabular}{|c|c|c|c|c|c|}
\hline \multirow{2}{*}{ Sampling point } & \multirow{2}{*}{ Examinated species } & $\mathrm{Ni}$ & $\mathrm{Pb}$ & Cd & $\mathrm{Zn}$ \\
\hline & & \multicolumn{4}{|c|}{ [mg/kg dry wt.] } \\
\hline \multirow{6}{*}{$\begin{array}{l}\text { S1 - Lapus River } \\
\text { upstream from } \\
\text { Baiut settlement }\end{array}$} & Equisetum fluviatile $\mathrm{L}$. & 43.0 & 295.9 & 26.9 & 6.8 \\
\hline & Carexacuta $L$. & 39.4 & 507.8 & 36.1 & 2.7 \\
\hline & Alismalanceolatum With. & 74.4 & 1008.1 & 52.3 & 28.2 \\
\hline & Alismalanceolatum With. & 113.6 & 1582.5 & 41.7 & 33.3 \\
\hline & CarexaquatilisWahlenb & 66.9 & 251.5 & 9.9 & 2.6 \\
\hline & Myosotonaquaticum(L.) Moench & 72.0 & 1365.6 & 124.4 & 14.1 \\
\hline \multirow{5}{*}{$\begin{array}{c}\text { S3 - Lapus River } \\
\text { downstream from } \\
\text { Bloaja pond }\end{array}$} & CarexhumilisLeyss. & 242.4 & 1864.6 & 27.4 & 33.1 \\
\hline & Salix exigua Nutt. & 183.5 & 1671.0 & 43.4 & 17.4 \\
\hline & Carexacuta $L$. & 129.3 & 2063.9 & 6.5 & 10.2 \\
\hline & CarexaquatilisWahlenb & 240.1 & 2557.1 & 41.6 & 30.3 \\
\hline & Salix fragilis & 251.5 & 594.0 & 54.2 & 27.5 \\
\hline \multirow{4}{*}{$\begin{array}{l}\text { S4 - Lapus River } \\
\text { downstream } 2 \mathrm{~km} \\
\text { from Bloaja pond }\end{array}$} & Salix exigua Nutt. & 121.3 & 321.4 & 98.1 & 10.0 \\
\hline & Menthaaquatica L. & 205.9 & 463.8 & 113.9 & 24.9 \\
\hline & Carexelata All. & 117.5 & 306.3 & 16.6 & 5.4 \\
\hline & Juncuseffusus L. & 135.0 & 1068.8 & 35.5 & 6.6 \\
\hline
\end{tabular}

The data provided by the toxicological analysis of the riparian vegetation shows that in the reference unpolluted section, plants from the Alismataceae family accumulate heavy metals, determined concentration in plants showing the pattern $\mathrm{Pb}>\mathrm{Ni}>\mathrm{Cd}$. Additionally, with regards to metal concentration in different species, $\mathrm{Pb}$ is bioaccumulated in the following order Alismataceae> Myosotonaquaticum $>$ Carexacuta $>$ Equisetum fluviatile $>$ Carexaquatilis.

The most contaminated, section 3, also records the highest concentrations of $\mathrm{Pb}$ and $\mathrm{Ni}$. In the identified Carex species the lead concentration was the highest, namely 1864.6 to $2557.1 \mathrm{mg} / \mathrm{kg}$ dry wt., but 
also in the two Salix species 594.0 to $1671.0 \mathrm{mg} / \mathrm{kg}$ dry wt., the nickel followed in the same species in the same order, i.e. Carex> Salix. Also, some species of the Carex family have a higher affinity for $\mathrm{Pb}$ and $\mathrm{Ni}$ than others. For $\mathrm{Pb}$, the critical toxicity level is reached at $0.6-28 \mathrm{mg} / \mathrm{kg}$ dry wt. and for nickel at $10-50 \mathrm{mg} / \mathrm{kg}$ dry wt., while the hyperaccumulation level is reached for both metals at concentrations higher than $1000 \mathrm{mg} / \mathrm{kg}$ dry wt. [15]. As a result, all plants identified in section 3 may be hyperaccumulators for metals.

For cadmium, the identified concentrations are kept within the same limits for all monitored sections with a higher bioaccumulation for Myosotonaquaticum of $124.4 \mathrm{mg} / \mathrm{kg}$ dry wt. in Section 1 and Mentha aquatica of $113.9 \mathrm{mg} / \mathrm{kg}$ dry wt. in Section 4, sections upstream and downstream from sources of heavy metal contamination.

Relative to the level of the metal concentrations in the structure of the plant, there are highlighted plants that are at the same time accumulators and "hyperaccumulators", the latter being characterized by the possibility of taking concentrations for $\mathrm{Cd}>100 \mathrm{mg}$ [16]. It is difficult to determine the critical level of toxicity for the chemical elements since usually small quantities are transported into the stem and the relevant toxic effect is sensed in the roots [15]. Under these circumstances it is possible that the two above-mentioned species have the characteristic of cadmium hyperaccumulators.

The bioconcentration rate heavy metals in riparian plants (the concentration of heavy metal in plant reported to the concentration of the same metal in sediments), in the studied sections is presented in Table 3.

Table 3. Bioconcentration rate for $\mathrm{Ni}, \mathrm{Pb}, \mathrm{Cd}$ in identified species

\begin{tabular}{|c|c|c|c|c|}
\hline Sampling point & Examinated species & $\mathbf{N i}$ & $\mathbf{P b}$ & $\mathbf{C d}$ \\
\hline \multirow{4}{*}{$\begin{array}{c}\text { S1 - Lapus River } \\
\text { upstream Baiut } \\
\text { settlement }\end{array}$} & Equisetum fluviatile L. & 2.2 & 7.0 & 16.8 \\
\cline { 2 - 5 } & Carexacuta L. & 2.1 & 11.9 & 22.6 \\
\cline { 2 - 5 } & Alismalanceolatum With. & 3.9 & 23.7 & 32.7 \\
\cline { 2 - 5 } & Alismalanceolatum With. & 5.9 & 37.2 & 26.1 \\
\cline { 2 - 5 } & CarexaquatilisWahlenb & 3.4 & 5.9 & 6.2 \\
\hline \multirow{3}{*}{$\begin{array}{c}\text { S3 - Lapus River } \\
\text { downstream } \\
\text { Bloaja pond }\end{array}$} & CarexhumilisLeyss. & 3.7 & 32.1 & 77.7 \\
\cline { 2 - 5 } & Salix exigua Nutt. & 4.8 & 2.7 & 13.9 \\
\cline { 2 - 5 } & Carexacuta L. & 2.6 & 2.5 & 22.0 \\
\hline \multirow{nyyyy}{*}{$\begin{array}{c}\text { S4 - Lapus River } \\
\text { - 2 km }\end{array}$} & CarexaquatilisWahlenb & 3.7 & 3.8 & 3.3 \\
\cline { 2 - 5 } downstream & Salix fragilis & 2.5 & 0.9 & 24.5 \\
\cline { 2 - 5 } Bloaja pond & Salix exigua Nutt. & 2.3 & 0.8 & 38.0 \\
\cline { 2 - 5 } & Menthaaquatica L. & 2.8 & 1.7 & 13.8 \\
\hline
\end{tabular}


For $\mathrm{Cd}$, the rate of bioconcentration was highest in section 1 for the Myosotonaquaticum species and decreasing as follows Asteraceae $<$ Carex< Equisetumfluviatile<Carexaquatilis. In sections 3 and 4 where the $\mathrm{Cd}$ concentration was similar with that in section 1 , the rate of bioconcentration was lower for the Carex species.In section S1, the Cd concentration measured in sedimentswas at a low level and constituted the metallogenetic background, so plants needed to adapt and developed different kinds of tolerance.

ForPb the rate of bioconcentration reported for the sediment load values was in reduced quantities, especially in sections 3 and 4 , even if identified plants have high registered concentrations. A much larger bioconcentration rate value was found in section 1 for all identified species, except Carex and Equisetumfluviatile.

For $\mathrm{Ni}$ the rate of bioconcentration remained in the 2.4-4.7 interval, with the exception of Asteraceae whose value was 5.9, even though the heavy metal load values of the sediment and implicitly of the plants differed between the 3 sections. With regards to the genus Carex, which is found in all 3 sections, the highest bioconcentration rate was found in section 3 , the most contaminated section.

These results indicate that the metal accumulation ability of plants differs between species, and affinity for one particular metal or another depends on its bioavailability.

The bioavailability of metals can vary seasonally, their toxicity for the benthic community can be maximal in autumn [17], when due to the decomposition of organic matter, anoxia with direct and indirect inhibitive effects can appear (due to the absence of $\mathrm{Fe}$ and $\mathrm{Mn}$ oxide co-precipitation in heavy metals).

\section{CONCLUSIONS}

Even after the cessation of mining activity water pollution is still present due to uncontrolled leaching processes. Is expected that the existent sediment loading will be supplemented with new quantities of heavy metals which are still being released from the polluted area, which is insufficiently protected.

The contamination level of the studied area was reflected in the vegetation that has the ability to take metals in proportion to their concentration in the environment. The plants have accumulated concentrations of $\mathrm{Cd}, \mathrm{Ni}$ and $\mathrm{Pb}$ far above their physiological needs, lacking the ability to distinguish the difference between necessity and excess.

All identified species are co-tolerant because they accumulate high concentrations of one metal $(\mathrm{Pb})$ and to a lesser extent of other metals (Cd), some of them are hyperaccumulators exceeding the "normal" level of concentration. 
The survival of plants in this heavily with metals contaminated body of water is owed to their adaptation, some through the bioaccumulation of metals others through the exclusion of concentrations which are greater than their carrying capacity. It can also be sustained through intake of nutrients and organic matter, but as plant diversity and abundance is reduced, for the observed conditions these two parameters are insignificant.

The study once again confirms that sediments can be the "memory" of quality events that occur on rivers and constitute at the same time as a reservoir of metals that they "supply" to aquatic organisms, implicitly to riparian plants.

The lack of measures to minimize the impacts of mining activity will keep the Lapus River, on the studied section, at risk of not satisfying good status as established by the WFD [9].

\section{EXPERIMENTAL SECTION}

\section{Study area}

The studied area is located in the Herja-Baiut metallogenic area, with an ore deposit with polymetallic mineralization (especially pyrite, galena and chalcopyrite) as well as gold and silver deposits mined until 2007. The Lapus River, which flows through the area, is affected by pollution originated from former mining activities, its chemical state risks not reaching the target of the Water Framework Directive and constitutes an exception to the general good status of the river.

The most important water pollution source is represented by acidic mine water, with a flow rate of about $3 \mathrm{l} / \mathrm{s}$, that is punctually discharged without treatment, through a gallery, the remainder being diffused in Lapus River. Other important pollution sources are represented by Bloaja-Baiut tailings ponds (12.7 ha) and the Bloaja Avarii pond (3.4 ha), which storage sterile(4\% pyrite) quantities of 1.027 million tons and 0.15 million tons, respectively. Non-certified Bloaja Avarii pond continues to induce a significant impact on the aquatic environment through the large quantitiesof tailings that are mobilized by rains and driven towards the Lapus River. In dry weather the windalso transports large quantities of fine dust contributing to general pollution of the area.

\section{Sampling and analyzing}

Compared to the operational monitoring sections established on the Lapus water body - "Izvorul Alb-Negru - Suciu and the tributaries" by the water basin authority, following "in situ" investigations, to determine the 
level of contamination and the transport of contaminants downstream, 4 other sections (located inside this body of water) were established where samples of sediment and riparian vegetation were taken in order to capture the significant impacts of shale mining activity (Fig. 1).

Sediment and riparian vegetation sampling was performed in early autumn, September 2016, from the same sections. The riparian vegetation samples were taken from the soil, which develops in shore areas with depths of less than $1.5 \mathrm{~m}$, depending on their representativeness and abundance, so as to be as relevant as possible for the proposed study.

Samples of the first $5-10 \mathrm{~cm}$ of the river deposits were collected in acid rinsed polyethylene bottles. All samples were kept in cooling boxes, at $4^{\circ} \mathrm{C}$ during transportation, and the analyses were performed immediately after receiving the samples in the laboratory. The collected sediment samples were air-dried, large particles were hand-picked and the rest was ground to powder. The fraction $<50 \mu \mathrm{m}$ was used for analyzing metals. Dry sediment was digested using aqua-regia in microwave digestion system (Berghof microwave oven). The mineralized mixture was cooled to room temperature, filtered and ultrapure water was added to the filtrate in a volumetric flask up to $100 \mathrm{~mL}$ mark.

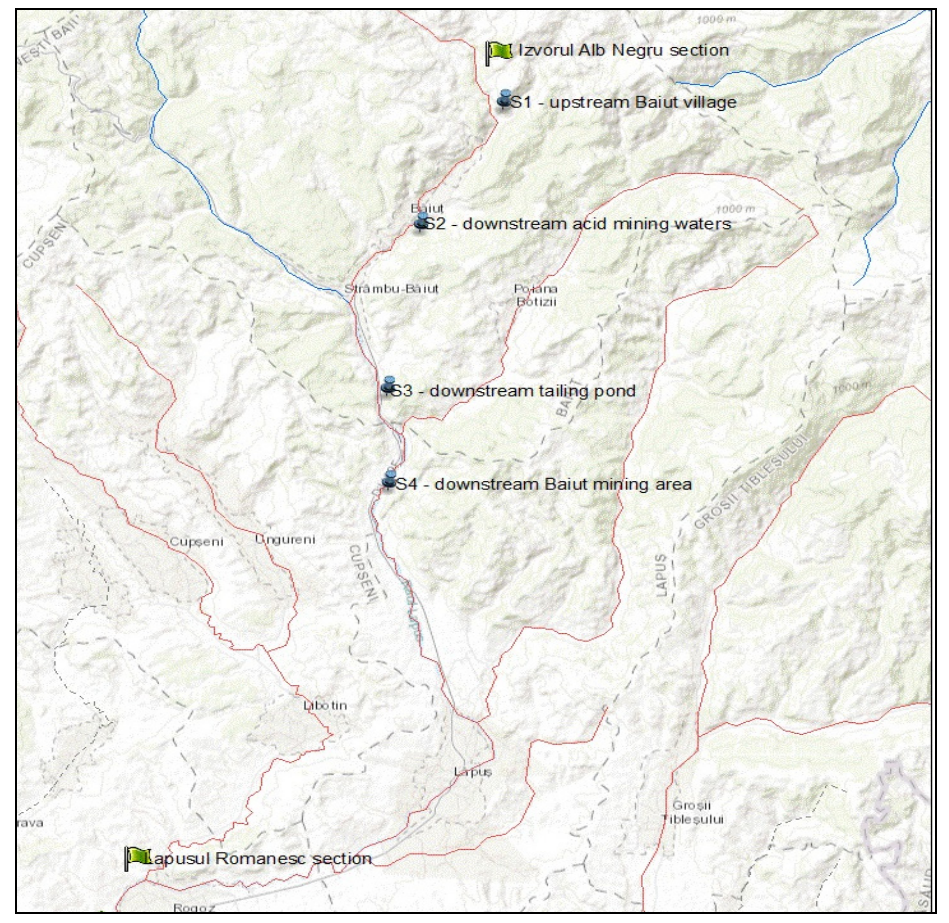

Figure 1. Placement of additional monitoring sections 
The sampled plants were washed of periphyton and sediment and stored in plastic bags. The plants were washed with distilled water and dried at room temperature, then in the dryer for 24 hours at $105^{\circ} \mathrm{C}$. The dried plants were ground to powder and were digested using a $\mathrm{HNO}_{3}$ and $\mathrm{H}_{2} \mathrm{O}_{2}$ mixture in a microwave digestion system (Berghof microwave oven). The mineralized mixture was cooled to room temperature, filtered and ultrapure water was added to the filtrate in a volumetric flask up to $50 \mathrm{~mL}$ mark.

The obtained solutions were then analyzed for heavy metal content using atomic absorption spectrophotometry (SHIMADZU AA-6800 spectrometer) in the Somes Tisa water basin laboratory.

The results for sediment and plants analysis were carried outwith anuncertainty interval of $\pm 5 \%$, the determinations being realized in conformity with ISO standards.

The operation conditions were those recommended for each metal in the instrument's method (Table 4).

Table 4. Instrumental parameters for metal determination by AAS

\begin{tabular}{|l|l|l|l|}
\hline Standard conditions & $\mathbf{C d}$ & $\mathbf{N i}$ & $\mathbf{P b}$ \\
\hline Wavelength, $\lambda[\mathrm{nm}]$ & 228.8 & 232 & 283.3 \\
\hline Slit width $[\mathrm{nm}]$ & 1.0 & 0.2 & 1.0 \\
\hline $\mathrm{HCL}^{*}$ current $(\mathrm{mA})$ & 8 & 12 & 10 \\
\hline Background & Deuterium & Deuterium & Deuterium \\
\hline Flame & $\mathrm{C}_{2} \mathrm{H}_{2} /$ air & $\mathrm{C}_{2} \mathrm{H}_{2} /$ air & $\mathrm{C}_{2} \mathrm{H}_{2} /$ air \\
\hline fuel flow $(\mathrm{N} \mathrm{I/h})$ & 1.8 & 1.6 & 2.0 \\
\hline
\end{tabular}

${ }^{*} \mathrm{HCL}$ - Hollow-Cathode Lamps

For each type of sample, sediment or plant, the analysis method included the determination of detection and quantification limits, necessary for obtaining validated results. Furthermore, the results validation was certified by the verification methodology on the accreditation standard SR EN ISO/IEC 17025:2018 [18].

The sensitivity of the AAS method was estimated as the limit of detection (LOD) and the limit of quantification (LOQ), which are presented in Table 5.

LOD and LOQ were calculated based on the standard deviation of the response and the slope, using the following equations [19-21]. 


$$
L O D=\frac{3 \times \sigma}{S} \quad L O Q=\frac{10 \times \sigma}{S}
$$

where, " $\sigma$ " is the standard deviation of 10 replicate measurements of the blank signal and " $S$ " is the slope of calibration curve.

Regarding $\mathrm{pH}$ of water, the measurement in situ was done with a portable pH-metre ( Hach analyzer), in each sampling section.

Table 5. LOD and LOQ of the AAS method

\begin{tabular}{|l|c|c|c|}
\hline \multirow{2}{*}{ Parameter } & \multicolumn{3}{l}{ Element } \\
\cline { 2 - 4 } & $\mathbf{C d}$ & $\mathbf{N i}$ & $\mathbf{P b}$ \\
\hline Linear working range $[\mathrm{mg} / \mathrm{kg}]$ & $0-50$ & $0-150$ & $0-200$ \\
\hline LOD $[\mathrm{mg} / \mathrm{kg}]$ & 1 & 6 & 13 \\
\hline LOQ $[\mathrm{mg} / \mathrm{kg}]$ & 5 & 20 & 50 \\
\hline
\end{tabular}

At the time of the sampling, submerged macrophytes were not identified in any of the sections, and the diversity of species was reduced, even in the reference section (the first proposed section, upstream of Baiut settelments). The identification of plant species or families was carried out by the biology laboratory of the basin water authority based on the determinator of plants. The identification of the species was difficult, and in some cases only the family of which the plant belongs could be identified, due to the similarities of the physiological characteristics due to the lack of the elements that differentiate them in the conditions of the end of the vegetation.

\section{REFERENCES}

1. A. J. M. Baker, P. L. Walker, Chemical Speciation \& Bioavailability, 1989, 1(1), 7.

2. A. J. M. Baker, New Phytologist, 1987, 106(1), 93.

3. H. Marschner, "Mineral nutrition of higher plants", 1995, London, Academic Press.

4. W. Larcher, "Physiological plant ecology", 2003, Berlin, Springer.

5. W. Ernst, Forest Snow and Landscape Research, 2006, 80(3), 251.

6. R. G. Turner, Ecological Aspects of the Mineral Nutrition of Plants, British Ecological Society Symposium, 1969, 9, 399.

7. S. M. Haslam, "River Plants. The macrophytic vegetation of watercourses", 2006, Forrest Text. 
8. S. M. Haslam, "River pollution: an ecological perspective", 1990, London, Belhaven Press.

9. Directive 2000/60/EC of the European Parliament and of the Council of 23 October 2000 establishing a framework for Community action in the field of water policy, published in the Official Journal OJ L 327, 22.12.2000.

10. Directive 2008/105/EC of the European Parliament and of the Council of 16 December 2008 on environmental quality standards in the field of water policy, amending and subsequently repealing Council Directives 82/176/EEC, 83/513/EEC, 84/156/EEC, 84/491/EEC, 86/280/EEC and amending Directive 2000/60/EC of the European Parliament and of the Council OJ L 348, 24.12.2008.

11. M. C. Sandoval, Proceedings of the 25th Annual British Columbia Reclamation Symposium, Campbell River, B.C., 2001, 67.

12. Order No. 161 of February 16, 2006for the Approval of the Normative on the Classification of Surface Water Quality in order to establish the ecological status of the water bodies (in Romanian). Eminent: Ministry of Waters, Forests and Environmental Protection (Published in: Official Gazette No 511 bis of 13 June 2006).

13. H. A. Elliott, M. R. Liberati, C. P. Chin-pao Huang, Journal of Environmental Quality, 1986, 15(3), 214.

14. J. S. Rieuwerts, I. Thornton, M. E. Farago, M. R. Ashmore, Chemical Speciation and Bioavailability, 1998, 10(2), 61.

15. M.J. Hodson, Biochemist, 2012, 34(5), 28.

16. R. R. Brooks, R. S. Morrison, R. D. Reeves, T. R. Dudley, Y. Akman, Proceedings of the Royal Society B, 1979, 203(1153), 387.

17. G. Krantzberg, Environmental Toxicology and Chemistry, 1994, 13(10), 1685.

18. SR EN ISO/IEC 17025:2018, General requirements for the competence of testing and calibration laboratories.

19.V. Thomsen, D. Schatzlein, D. Mercuro, Spectroscopy, 2003, 18(12),112.

20. C. C. Chan, "Pharmaceutical Manufacturing Handbook: Regulations and Quality", 2008, edited by Shayne Cox Gad, John Wiley \& Sons, Inc., pp 727-742.

21. H. Sun, L. Li, American Journal of Analytical Chemistry, 2011, 2, 217. 
